\title{
Py-school-match: Matching algorithms to assign students to schools
}

\author{
lacopo Garizio ${ }^{1}$ \\ 1 Pontificia Universidad Católica de Chile
}

DOI: $10.21105 /$ joss. 01111

\section{Software}

- Review ¿

- Repository cta

\section{Summary}

- Archive [T

Submitted: 28 November 2018 Published: 04 February 2019

\section{License}

Authors of papers retain copyright and release the work under a Creative Commons Attribution 4.0 International License (CC-BY).

In many countries where schools cannot discriminate among student applicants (no entrance exams, no interviews, no previous grades examination, etc.), there is always one question that cannot be answered directly: How to assign students fairly and efficiently?

Over the years, there have been many proposed solutions to this problem. These vary from simple "lotteries" (random priority assignment) to more complex graph algorithms. Because each option has its own strengths and weaknesses, and given that in the real world there is an extra layer of requirements (quotas, special conditions, ranks of preference, etc.) it is vital to analyze and simulate every available option. The correct selection of the algorithm can have serious effects on efficiency and fairness, as it has been exemplified by studies conducted in school systems from Boston (P. Abdulkadiroğlu Atila \& Roth, 2005a) and New York (P. Abdulkadiroğlu Atila \& Roth, 2005b, 2009)).

py-school-match is a Python library that implements multiple matching algorithms and aims to ease the process of choosing the best alternative for each school system. It allows researchers to simply specify the country's requirements or conditions, and then run interchangeably the different algorithms to compare their results. What makes py-s chool-match different from other libraries is that it is specifically created to be used in the the student-to-school assignment problem. Another distinctive characteristic is that it allows the use of quotas, priorities, capacities, among others, without much effort.

py-school-match implements the following algorithms:

- Top trading cycles (TTC) (A. Abdulkadiroğlu \& Sönmez, 2003)

- Deferred acceptance with multiple tie-breaking (DAMTB) (Roth \& Shapley, 1962)

- Deferred acceptance with single tie-breaking (DASTB) (A. Abdulkadiroğlu \& Sönmez, 2003)

- Stable improvement cycles (SIC) (Erdil \& Ergin, 2008)

- Deferred acceptance with multiple tie-breaking, plus stable cycles (MSIC)

- Deferred acceptance with single tie-breaking, plus non-stable cycles (NSIC)

\section{Acknowledgement:}

I would like to thank my advisor, Nicolás Figueroa, for his valuable feedback. 


\section{References}

Abdulkadiroğlu, A., \& Sönmez, T. (2003). School choice: A mechanism design approach. American Economic Review, 93(3), 729-747. doi:10.1257/000282803322157061

Abdulkadiroğlu, P., Atila, \& Roth, A. (2005a). The boston public school match. American Economic Review, 95(2), 368-371. doi:10.1257/000282805774669637

Abdulkadiroğlu, P., Atila, \& Roth, A. (2005b). The new york city high school match. American Economic Review, 95(2). doi:10.1257/000282805774670167

Abdulkadiroğlu, P., Atila, \& Roth, A. (2009). Strategy-proofness versus efficiency in matching with indifferences: Redesigning the new york city high school match. The American Economic Review, 99(5), 1954-1978. doi:10.3386/w14864

Erdil, A., \& Ergin, H. (2008). What's the matter with tie-breaking? Improving efficiency in school choice. American Economic Review, 98(3), 669-689. doi:10.1257/aer.98.3.669

Roth, \& Shapley. (1962). College admissions and the stability of marriage. The American Mathematical Monthly, 69(1), 9-15. doi:10.2307/2312726 